\title{
Destination Decision-Making Process Based on a Hybrid MCDM Model Combining DEMATEL and ANP: The Case of Vietnam as a Destination
}

\author{
Thi Hai Ninh Do, Wurong Shih \\ College of Business, Southern Taiwan University of Science and Technology, Taiwan \\ Email: Haininh_do@hotmai.com
}

Received 30 May 2016; accepted 13 August 2016; published 16 August 2016

Copyright (C) 2016 by authors and Scientific Research Publishing Inc.

This work is licensed under the Creative Commons Attribution International License (CC BY).

http://creativecommons.org/licenses/by/4.0/

c) (i) Open Access

\begin{abstract}
The purpose of this study is to identify the main factors influencing a traveler's Destination Decision-Making Process (DDMP) by applying a hybrid Multi-Criteria Decision-Making (MCDM) model. To examine the relationship among the three dimensions such as tourist motivation, information searching process, decision making of the DDMP, the MCDM model, combining decision-making trial and evaluation laboratory (DEMATEL) and Analytic Network Process (ANP), was adopted. Based on a literature review, six main perspectives and fifteen criteria were extracted and subsequently validated by six tourism experts. A questionnaire was then constructed and answered by both tourism experts and tourists. The results show that the external search is the most important perspective, and it also influences the remaining perspectives. Furthermore, this work presents the criteria for each perspective. By proposing strategies to academics and practitioners, this study can serve as a valuable guide and reference for travel destinations in order to attract more tourists.
\end{abstract}

Keywords

Destination, Decision-Making Process (DMP), DEMATEL

\section{Introduction}

International destinations have increased their competitiveness by making their places more attractive to tourists. Hence, destination and tourism related topics have attracted a growing amount of attention in recent years be-

How to cite this paper: Do, T.H.N. and Shih, W. (2016) Destination Decision-Making Process Based on a Hybrid MCDM Model Combining DEMATEL and ANP: The Case of Vietnam as a Destination. Modern Economy, 7, 966-983.

http://dx.doi.org/10.4236/me.2016.79099 
cause of their role as the predominant sector in the global economy. As such, discussions on topics related to tourism have proliferated, not only in academia but also in business practices as well. The rapid growth of the Internet has created two-way communications [1] on the web, which have led to the emergence of online Social Network Sites (SNSs) and services [2] within tourism. Therefore, tourism is ranked as the foremost industry in terms of volume of online transactions [3]. Heinemann [4] showed that SNSs were being progressively used by travelers who also were SNS users. Many SNSs enable users to post and share travel-related comments, opinions, personal experiences, and videos or pictures. These can serve as information for others. Gretzel and Yoo [5] argued that SNS content played a pivotal role in a tourist's search for destination information. Through SNS two-way communication, tourists have communicated not only with tourism operators but also with experienced tourists [6]. However, tourists' lack of experience, travel agents were the most importance source when searching for information, besides that, guidebooks, brochures and videos from tourist offices were also used by traditional travelers [2].

Wong and Yeh [7] claimed that tourist decision making had always been a central issue to the tourism industry. Many researchers look for relationships with other sectors of human activities to explain and predict the phenomenon of tourism by taking a marketing and tourist decision-making [8]. Additionally, DDMP is complex because it involves many sub-decisions, deriving from the pre-purchase information search process. Tourists search for information through various channels; accordingly, SNSs are growing tremendously. Based on these studies, our study endeavors to develop a decision tree with tourist DDMP to find ways to enhance tourist DDMP and improve tourism destination. Hence, a hybrid MCDM model, which combines DEMATEL and ANP, is used to detect complex relationships. To build a Network Relation Map (NRM), the ANP technique is suggested to have the power to solve dependence and feedback problems. By combining the DEMATEL and ANP methods, the DANP approach can be used to calculate the influential weight of decision-making criteria to overcome problems of DDMP among criteria and alternatives, according to the ANP theory by Saaty [9].

This study, then, is expected to give directions and suggestions that can help tourism businesses better understand tourist-SNS users. This, in turn, can help experts make decisions when creating marketing strategies to promote destinations. Furthermore, this study can contribute to the recently emerged theoretical effort of using the role of SNSs as external factors, or push factors, when obtaining information for motivation theories.

\section{Literature Review}

\subsection{Motivation-Push and Pull Theories}

Many researchers have done research on tourist motivation [10]. Goeldner and Ritchie [11] pointed out that a tourist's motivation is regarded as the internal psychological factors, and must be related to needs and personal goals, which consider the tourist's motivation from a long-term, multi-motive, nondeterministic view for particular travel groups. Based on the above studies, Li and Cai [12] suggested that a tourist's motivation is regarded as one of the most important variables explaining tourist behavior. However, tourist motivation is a complex subject that explains individual DDMP and the reason why tourists behave the way they do, both before and during their holidays. Understanding of the basic motivations is key to fulfilling a tourist's desires [13]. Therefore, marketers must understand the motivating factors that lead to tourist decision and tourist behavior in order to promote the destination.

The most widely applied psychological motivation theory in tourism is Maslow's hierarchy of need [14], which divided human needs into two psychological categories with five fundamental component hierarchies. Dann [15] linked his tourism motivator study to Maslow theory, and then came up with two factors for choosing a destination, namely push and pull factors. Push factors refer to the intrinsic needs; on the other hand, pull factors relate to the external ones. Richard [16] suggested that tourists were motivated to visit a destination by information received from generating markets which match the tourist needs and wants. Hence, understanding the foundation of tourist motivation can help tourism organizations or companies to maintain and develop locations to attract more tourists.

\subsection{Information Process Models}

Information searching is potentially the greatest factor involved in a tourist's pre-travel experience. Since the Internet possesses the capability for a high level of interactivity, it has grown to be one of the most effective 
means for a tourist to seek information and to purchase tourism-related products [17]. The use of the Internet has changed the way in which information is collected, stored, distributed, processed, and managed in tourism. Assael [18] identified an information acquisition and processing model, which describes the five stages individuals proceed through before deciding whether to purchase a product. These are input variables, information acquisition, information process, brand evaluation, and actual purchase or use of the product. Accordingly, this fivestage model states the DDPM, so potential tourists have access to information which is necessary for choosing a destination, therefore, reducing the level of uncertainty, and enhancing the quality of the trip [19]. This model not only allows the tourists to do a more accurate information search in terms of finding adequate internal information first, and then external information later in order to satisfy their needs, but also examines the consumer characteristics which will play a major role in the information search process. Tourist characteristics motive a tourist's use of prior knowledge or experience as an information tool and also as their push motive to make their final decision before search information from external sources. According to Kerstetter and Cho [20], prior knowledge has been identified as a main factor that is affected by an information search on the Internet. These issues are concerns in this research, as the relationship between former knowledge and a tourist's information search process has both a positive and negative impact on DDMP.

\subsection{Decision Making Theories}

Many decision-making theories have been introduced, and most of them have proposed consumer behavior, and product, which the consumer knows, trust, and then purchase. According to the Kim and Srivastava [21] paper presented at the Proceedings of the ninth international conference on Electronic commerce, the decision making of consumers consists of some stages, such as need recognition or awareness, information search, evaluation, purchase, and after purchase evaluation. The study of consumer decision making has grown exponentially among researchers for a few decades and has given rise to several theories such as theory of planned behavior [22], and the theory of reasoned action [23].

The above theories of consumer behavior have been transformed and adopted by researchers in terms of travel behavior, e.g., a useful approach to understand travel behavior. Woodside and Jacobs [24] said that tourists (decision-making process) DMP was complex, and it is influenced by consumer behavior [25]. Sirakaya and Woodside [26] also proposed substantial conceptual and empirical work to describe the tourist DMP model. Fuller, Wilder, Hanlan and Mason [27] suggested that researchers in tourism are concerned with the travel-purchase decision, which can be affected by both internal and external variables. In addition, Middleton [28] presented a model of travel DMP. This model found five components of the travel decision process: stimulus input, communication channels, buyer characteristics and decision process, and purchase output. In his study, Middleton indicated motivation as a dynamic variable in travel behavior, bridging the gap between the felt need and the decision to act or purchase.

\subsubsection{Tourist Motivation with DDMP}

Tourist motivation is a dynamic process: combining the internal, or push, factors with the external, or pull, factors. Devesa, Laguna, and Palacios [29] stated the "push" of tourist motivation is used to explain the desire to go on vacation from their characteristics, while the "pull" is used to explain the destination characteristics that attract tourists.

\section{Tourist Characteristics}

The tourist is first motivated by given "push factors" to choose a place for vacation. Wolfe and Hsu [3] said the individual has to make a decision, whether to go on an excursion or to stay at home. This decision is based on an assessment the individual's socio-demographic and personality. Socio-demographic characteristics have been extensively studied as explanatory variables for an evolved set of alternative destinations and antecedents of information processing. Moreover, many models of the DMP in the choice of tourist destination [30] show that the individual's personal characteristics, such as gender, age, occupation, education, social class, and socio economic, influence the perception of destination, are involved in the decision making process. Furthermore, other tourism researchers have shown that tourist characteristics are related to tourist personality [31]. The personality factors affect one's cognitive organization of perceptions, which also influence the perceptions of the environment and the resulting image. Based on the research of Plog [31] no person is a perfect example of any personality type, but the personality scale helps to explain why destinations rise and fall in popularity. Therefore, 
in this research, tourist personality characteristics were selected as a factor in the decision making process when choosing a destination.

\section{Destination Characteristics}

Tourism is closely linked to environment characteristics. People travel because everyday life and familiar surroundings make them feel bored hence, a new environment at a long-distance from home may help travelers to find their everyday life more enjoyable. According to the definition of Fridgen [32], destination environment refers to both the social and physical characteristics surrounding an individual. Seasonality has long been recognized as an issue with climate dependent destinations, as seasonal change and climate change also change predictability according to what a tourist normally expects. That is to say, knowing about an environment can provide a good deal of information about the people who interact with it. In recent years, consideration of all constraints and image attributes, social characteristics such as culture, safety, security, and socio-economic has become some of the most perceived inhibitors preventing potential tourists from traveling to their preferred destinations.

Tourism is an industry based on the imagery of the destination. Tourist motivation relates to a destination's "pull factor," which attracts tourists to that destination. In addition, according to Beerli and Martín [33], the characteristics of both the motivation and information affect the destination image. Before tourists travel to a destination, they develop an image and a set of expectations about this destination. Therefore, understanding the image of a destination is essential for a destination hoping to influence traveler DMP. Chon [34] found that a positive image has a significant impact on tourist DDMP; whereas, a negative image showed a non-significant impact. Hence, destination image is a significant factor in understanding the destination selection process and plays a crucial role in tourist DDMP, as tourists typically choose the destination with the most favorable image to them.

Destination branding is one of the research areas of academic interest in tourism [35]. Although the DMP of a tourist when selecting a vacation place is very complex, one of element is destination brand, which is fundamental for a nation hoping to have a good reputation, as that could increase its competitiveness and attractiveness to tourists. A destination brand can be defined as "perceptions about a place as reflected by the associations held in tourist memory" [36]. Murray [19] argued that destination brand is a key component that links destination images with consumer decision. The branding technique has become a powerful tool for tourist destination marketers because a brand can identify the destination through a positive image that has a direct impact on tourist decision-making.

\subsubsection{Information Searching Process with Tourist DDMP}

Many researchers have proposed that information plays a central role in the context of tourism. Both the destination selection process and behavior at a destination were prominent elements in tourism decision-making. Fodness and Murray [19] suggested information search strategies both affect and are affected by characteristics of the tourist, and some components of motivation and information search also have a direct influence in determining an intention to visit a destination. Ho, Lin and Chen [37] indicated that tourism information research includes internal searches as well as multiple external information sources. Sharon and Smith [38] claimed that people usually attempt to search for information in their memory first, and if an inner information source does not work, they then will search externally for relevant information. Based on the above studies, we concluded that tourists recognized a need to go to travel through push and pull motives. This information search, which is the second stage of tourist DM, is the motivated activity to search for information stored internally or the acquisition of information externally.

\subsection{Internal Search}

Whenever travelers realize that they need to decide upon a destination, an information search is likely to take place. Initially, it takes place internally. Previous experience and knowledge are used as the basic information for making a decision [19]. One of the most important factors influencing the DMP in tourism has proven to be one's experiences with a variety of places and activities. Hence, Murray proposed that when faced with a purchase decision, the consumer first examinees information in their memory about past purchasing experience, including the knowledge about products from previous learning or in long-term memory. In addition, previous research suggests that amount of experience influences the acquisition of incoming information for a plan of the 
trip [20].

As decision-making is a highly contingent form of information processing, prior knowledge is considered to be a rudimentary determinant of an individual's information search behavior. Consumer behavior research has consistently examined the effect of variables related to earlier knowledge, such as familiarity or product experience. Furthermore, other research has asserted that subjective knowledge provides a better understanding of a decision maker's systematic biases. While investigating the effect of prior knowledge on information search behavior, Dipietro, Wang, Rompf and Severt [39] found that a high probability of the use of external information sources to make vacation decisions is used by travelers during the first stage of product knowledge.

\subsection{External Search}

Hyde [40] suggested that when information does not already exist within the knowledge and memory of a tourist, it may be sought from exterior sources. Therefore, when a traveler is not familiar with the product, external search behavior once again becomes important to the destination decision. Evidence suggests that travelers are likely to utilize the following external information sources when planning their trips: WOM, Tourism intermediate, Internet. Research has shown that WOM, or word of mouth advice from the friends and relatives, often ranks as the most influential source of pre-purchase information. Consumers tend to rely on WOM to reduce their level of perceived risk and uncertainty [1]. WOM has long been recognized as one of the most important external sources of information for travel planning and travel-related product purchases [41].

Tourism in the past used many different intermediaries in the delivery of a tourism product starting with the travel agent [42]. Information from professional sources like tour operators or travel agencies only plays a significant role before a definite trip decision is made. Recently, Gretzel, Hwang and Fesenmaier [43] found that travel information played an important role in promoting the economic benefits of tourism, as tourists tend to use information materials which they pick up at acenter.

Many definitions of an SNS from various researchers and authors can be stated as "a platform that enables users to publicize personal information and to share with others with common interests and activities" [44]. One mega-trend has noticeably emerged on the Internet, underscoring changes that can significantly impact the tourism system. Nearly $50 \%$ of travel purchasers visited a forum, or online community, before making their decision [1]. This is the so-called SNS, which represents various forms of consumer-generated content, such as blogs, Facebook, and Linkedin. Media files shared on sites like YouTube and Flick have also gained substantial popularity in online travelers' use of the Internet [45].

According to studies about the potential usefulness of online SNS for tourism, researchers have found that information searches and information sharing through e-WOM communications have been prominent for travel and tourism marketers in developing marketing programs for destinations. They are equally important to tourists when making their decision to choose a destination [46]. Miguens, Baggio \& Costa [47] said that online social travel networking is changing the way tourists plan their trips. Kattiyapornpong and Kenneth [48] showed that Internet information search and DDMP and SNSs are pervasive factors for travelers seeking information and booking tours. From a lot of travel websites, forum, searching information through SNSs is more reliable and suitable since it is small comunication between friends, colleges, family and relatives. Also, people are being motivated by watching photos, videos from their friend about new travel trip, destination. Many researchers suggested the travel industry should look to SNSs (especially Facebook) as a powerful source of traffic for conversion to transactions in the travel planning process.

\section{Travel Planning with DDMP}

\section{Planning Characteristic}

The purpose of the trip is perhaps the greatest influence on the DMP. Dwyer, Forsyth, and Rao [49] found that consumers' purchase decisions are influenced by the type, purpose of product, and information sources used. In additional, travel distance has an important role in travel planning. The influence of distance on human behavior is perhaps most vividly expressed in the way in which the overcoming of distance imposes a major constraint on travel behavior [50]. According to research on travel distance by the international tourist to New Zealand, Becken and Schiff [51] found that the influence of distance with DDMP of tourist decreased slightly.

Decrop and Snelders [52] found that length of stay, or the amount of time the tourist has available at destination, is one of the key elements in a tourist's DDMP. Related to DDMP, the vacationer's length of stay at the destination is another variable that influences purchase behavior [53]. 


\section{Decision Choice Set}

Many researchers' study models of pre-vacation decision making initially examined a single issue: the tourist's choice of a vacation destination [54]. When tourists have collected all the relevant information, they have to evaluate the different alternatives identified in the search of the DDMP. Hence, the information used to evaluated trip's characteristics help tourists makes their decision. However, destination choice is made by an evaluation of the alternatives based on individual preferences and goals. Therefore, evaluation of travel and tourism services is a complex process for any tourist. Furthermore, this evaluation also brings a high level of perceived risk to decision making [55]. In a situation where the consumer is evaluating different tourism destinations, available time and assets have a high importance, as tourists are hopeful of getting to the destination within the least amount of time and at the lowest possible expense.

After having evaluated all the alternatives identified in the search of information stages, the individual is ready to make the final decision. The tourist has to make a decision from the best alternatives. Logic would dictate that purchase or bookings would proceed from the information search and vacation planning. Depending on the complexity of the decision, the consumer will spend more time on this stage, possibly re-evaluating all the alternatives. Because tourists tend to reduce the risk of purchasing an unsatisfactory product or service, sometimes they start to avoid the decision-making process and gather even more information from their friends and relatives, and they tend to prefer already reputable brand names and guarantees.

\section{Research Design and Methodology}

The decision-making trial and evaluation laboratory (DEMATEL) method was created and developed by the Science and Human Affairs Program of the Battelle Association of Geneva Research Center between 1972 and 1976 [56] [57]. It was used to study and solve this complicated and difficult problem. DEMATEL is a potent method that helps with gathering group decision making by forming a structural model, as well as dealing with large problems [58]. Conceptually, a large problem is not easy to solve directly; hence, it is broken down into slighter problems, which evaluate the relationship between these smaller sub-problems discovered through collective data. In this research, the relationship between tourist DDM and SNS is multi-faceted. Thus, DEMATEL was applied to solve the problem of tourist DDM by broken problem into cause and effect group.

The DEMATEL method finds the interrelations between entwined criteria. According to factor analysis results, some experts were invited to discuss the relationships and influence level of criteria under the same factor, and to score the relationships among criteria based on the DEMATEL method. Factors were divided into different types, so the experts could answer the questionnaire in areas they were familiar with. In order to limit information loss from DEMATEL method results, threshold values were decided upon after discussion with these experts, and an acceptable impact-digraph-map was found.

As ANP and DEMATEL have these advantages, this paper proposes an effective solution based on a combined ANP and DEMATEL approach to help the tourism industry (See Apendices for the calculation part). An integrated MCDM technique combining the DEMATEL and ANP methods can overcome the problem of interdependence and feedback between criteria and alternatives [59]. This combined method has been successfully used in various fields for purposes such as evaluation for tourism policy [60] and the performance of a hot spring hotel [61]. In the framework of this research (Figure 1 and Table 1), the literature review claimed that some criteria and elements influence others, which implies interaction among elements of destination decision-making. When making the decision to choose a destination, not only tourists but also the tourism companies need to consider the interrelationship of these factors to distribute and store factors in networking allocation.

\section{Analysis and Results}

\subsection{Experts}

In this research, our survey took place from February until July 2013 in Vietnam, and was divided into two stages. A list of criteria, which affect DDMP, was collected from a comprehensive literature review. The questionnaire survey was designed in stage one to help narrow down the list and to find important criteria by asking 6 experts their opinions on the relative importance of the given criteria. After narrowing down the questionnaire, in the second stage sixteen experts were invited to evaluate the influence among criteria in the DEMATEL survey. 
Table 1. Destination decision-making criteria.

\begin{tabular}{|c|c|c|c|}
\hline Goal & Aspects & Objective & Criteria \\
\hline \multirow{15}{*}{$\begin{array}{c}\text { Destination } \\
\text { Decision } \\
\text { Making }\end{array}$} & \multirow{5}{*}{ Motivation } & \multirow{2}{*}{ Tourist Characteristics (A1) } & Social-demographic (C1) \\
\hline & & & Personality (C2) \\
\hline & & \multirow{3}{*}{ Destination Characteristics (A2) } & Environment (C3) \\
\hline & & & Image (C4) \\
\hline & & & Brand (C5) \\
\hline & \multirow{5}{*}{$\begin{array}{l}\text { Information } \\
\text { Searching Process }\end{array}$} & \multirow{2}{*}{ Internal Search (A3) } & Memory (C6) \\
\hline & & & Knowledge (C7) \\
\hline & & \multirow{3}{*}{ External Search (A4) } & WOM (C8) \\
\hline & & & Social Network Sites (C9) \\
\hline & & & Tourism Intermediate (C10) \\
\hline & \multirow{5}{*}{ Travel Planning } & \multirow{3}{*}{ Planning Characteristics (A5) } & Travel Purpose (C11) \\
\hline & & & Travel Distance (C12) \\
\hline & & & Length of Stay (C13) \\
\hline & & \multirow{2}{*}{ Choice Set (A6) } & Evaluation (C14) \\
\hline & & & Purchase (C15) \\
\hline
\end{tabular}

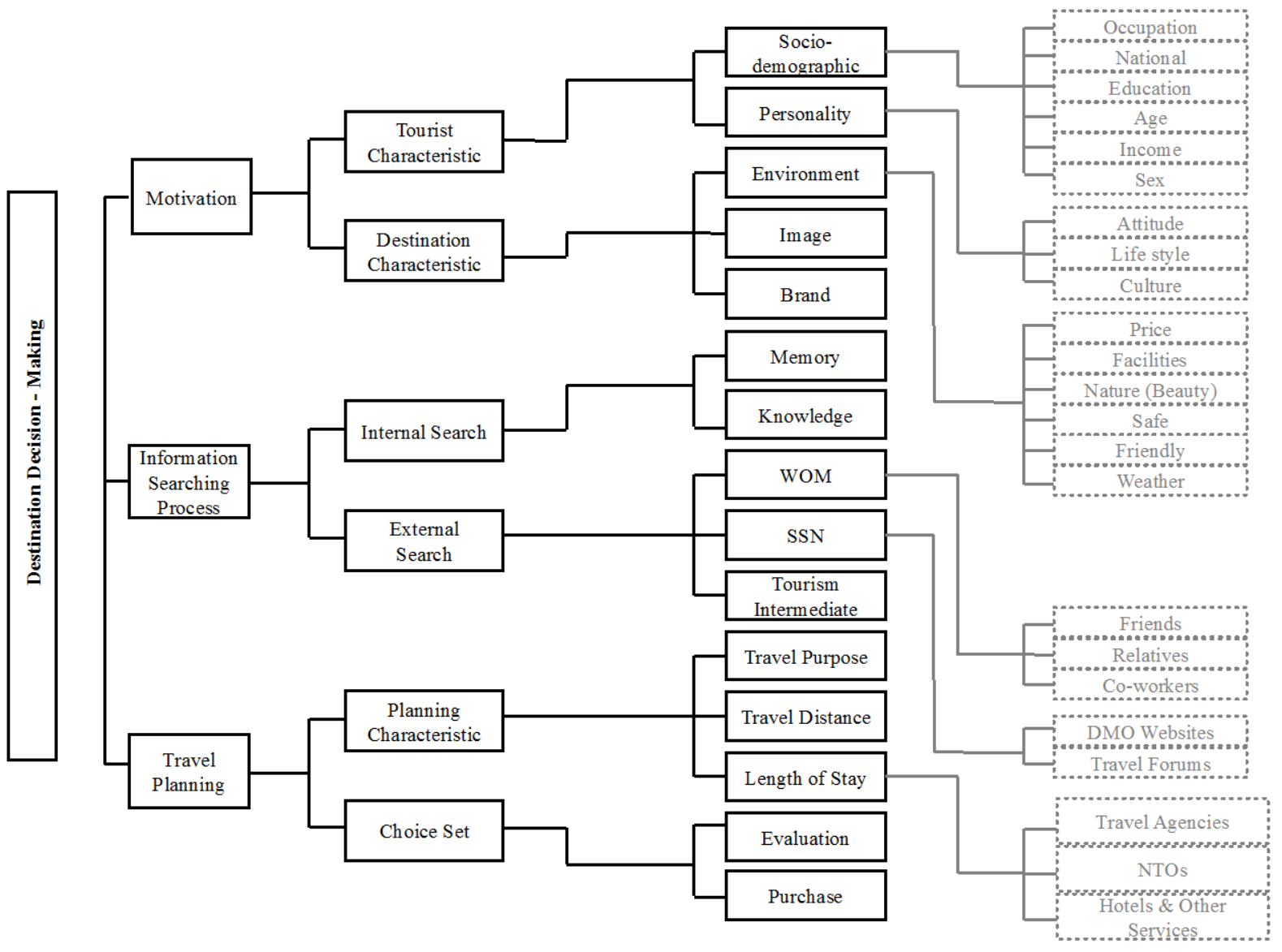

Figure 1. Research framework: Destination decision-making process. 
Both of the expert who attended in this study was have at least 5 years of working directly on tourism industry or at least 14 years indirectly working with tourism field (detail in Table 2). This result not only indicates the influential priorities and the most important criteria but also demonstrates the relationships between those criteria.

The aim of this research not only determines the most important factors of DDMP, but also measures the relationships among dimensions and criteria. The averaged initial direct relation $15 \times 15$ matrix obtained comparisons in terms of influences and direction between criteria (Table 3)

However, in order to reduce the complexity of the elements in the matrix, threshold value $\alpha$ was carefully calculated [62]. The threshold value $\alpha$ was calculated using the equation:

$$
\alpha=\sum_{i=1}^{n} \sum_{j=1}^{n}\left[t_{i j}\right]
$$

Finally, $\alpha$ is chosen with the value of $\alpha=0.86625$ and influence matrix after threshold $T$ is driven by above equation. Then, the results for the criteria, based on values of $d+r$ and $d-r$, are presented in Table 4, and also in NRM (Figure 2).

Table 2. Experts list for DEMATEL.

\begin{tabular}{|c|c|c|c|}
\hline Number of experts & Title & Expertise & Years (At least) \\
\hline 2 & Operation Manager & Tourism company & 5 \\
\hline 3 & Director & Tourism company & 5 \\
\hline 1 & Director & Vietnam Tourism Association (Website) & 7 \\
\hline 1 & General Manager & Hanoi Tourism Association & 15 \\
\hline 1 & Chief of Travel department & Hanoi Tourism Organization & 12 \\
\hline 2 & General Manager & Tourism Magazine & 17 \\
\hline 3 & Back Packer Tourist & $\begin{array}{c}\text { They also are operation manager of biggest website about } \\
\text { backpacker tourist in Vietnam }\end{array}$ & 8 \\
\hline 3 & Professor & Tourism department, Tourism College & 14 \\
\hline
\end{tabular}

Table 3. Total influence matrix-DEMATEL survey of experts.

\begin{tabular}{|c|c|c|c|c|c|c|c|c|c|c|c|c|c|c|c|}
\hline $\mathrm{T}$ & $\mathrm{C} 1$ & $\mathrm{C} 2$ & $\mathrm{C} 3$ & $\mathrm{C} 4$ & C5 & C6 & C7 & $\mathrm{C} 8$ & C9 & C10 & C11 & C12 & C13 & C14 & C15 \\
\hline $\mathrm{C} 1$ & 0.7747 & 0.8438 & 0.8522 & 0.8504 & 0.8507 & 0.8245 & 0.8488 & 0.8775 & 0.9154 & 0.8619 & 0.8558 & 0.8306 & 0.8529 & 0.8393 & 0.8329 \\
\hline $\mathrm{C} 2$ & 0.8516 & 0.8007 & 0.8669 & 0.8739 & 0.8731 & 0.843 & 0.8719 & 0.8929 & 0.9448 & 0.8706 & 0.8709 & 0.866 & 0.8702 & 0.8649 & 0.8469 \\
\hline C3 & 0.8461 & 0.8652 & 0.8045 & 0.8855 & 0.8662 & 0.8455 & 0.8678 & 0.8698 & 0.927 & 0.8795 & 0.8735 & 0.8578 & 0.862 & 0.853 & 0.8548 \\
\hline $\mathrm{C} 4$ & 0.8288 & 0.8454 & 0.8548 & 0.7968 & 0.862 & 0.8241 & 0.8535 & 0.8687 & 0.9128 & 0.8617 & 0.8534 & 0.8359 & 0.8469 & 0.829 & 0.8179 \\
\hline $\mathrm{C} 5$ & 0.7863 & 0.7939 & 0.7983 & 0.8118 & 0.7411 & 0.762 & 0.7857 & 0.828 & 0.8513 & 0.8046 & 0.7997 & 0.792 & 0.7978 & 0.7774 & 0.7669 \\
\hline C6 & 0.8721 & 0.8763 & 0.874 & 0.8954 & 0.8813 & 0.7949 & 0.894 & 0.9066 & 0.9435 & 0.8939 & 0.8973 & 0.8688 & 0.8844 & 0.883 & 0.8759 \\
\hline $\mathrm{C} 7$ & 0.8866 & 0.8963 & 0.9088 & 0.9172 & 0.9137 & 0.8656 & 0.8411 & 0.9256 & 0.9757 & 0.9104 & 0.9162 & 0.8914 & 0.9067 & 0.9 & 0.8878 \\
\hline $\mathrm{C} 8$ & 0.8915 & 0.8987 & 0.9197 & 0.9174 & 0.9112 & 0.8805 & 0.9114 & 0.8677 & 0.9736 & 0.9252 & 0.9163 & 0.8997 & 0.9091 & 0.9026 & 0.8979 \\
\hline C9 & 0.8915 & 0.9 & 0.9041 & 0.9194 & 0.9161 & 0.8584 & 0.9026 & 0.932 & 0.9059 & 0.9153 & 0.9283 & 0.9023 & 0.9054 & 0.911 & 0.8912 \\
\hline C10 & 0.8874 & 0.8885 & 0.8945 & 0.9138 & 0.8973 & 0.8678 & 0.8984 & 0.9149 & 0.967 & 0.842 & 0.9022 & 0.8857 & 0.8756 & 0.896 & 0.8852 \\
\hline C11 & 0.8974 & 0.9048 & 0.9184 & 0.9233 & 0.9075 & 0.8863 & 0.9199 & 0.9342 & 0.9823 & 0.9214 & 0.8561 & 0.9094 & 0.9092 & 0.9125 & 0.8978 \\
\hline C12 & 0.8312 & 0.854 & 0.8599 & 0.8715 & 0.8597 & 0.8234 & 0.8502 & 0.8779 & 0.9124 & 0.861 & 0.8632 & 0.7841 & 0.8604 & 0.8513 & 0.8349 \\
\hline C13 & 0.8902 & 0.89 & 0.9061 & 0.9147 & 0.9048 & 0.8775 & 0.9074 & 0.9375 & 0.9777 & 0.9176 & 0.9102 & 0.8924 & 0.8376 & 0.8975 & 0.877 \\
\hline C14 & 0.7931 & 0.8003 & 0.8008 & 0.8009 & 0.8066 & 0.7805 & 0.8035 & 0.8361 & 0.8658 & 0.8199 & 0.8128 & 0.7885 & 0.7893 & 0.7415 & 0.7839 \\
\hline C15 & 0.8 & 0.7996 & 0.8099 & 0.8116 & 0.8197 & 0.8044 & 0.8203 & 0.84 & 0.8759 & 0.8271 & 0.815 & 0.7937 & 0.817 & 0.8198 & 0.7413 \\
\hline
\end{tabular}


Table 4. Criteria influence-DEMATEL survey.

\begin{tabular}{ccccc}
\hline & $\boldsymbol{d}$ & $\boldsymbol{r}$ & $\boldsymbol{d}+\boldsymbol{r}$ & $\boldsymbol{d}-\boldsymbol{r}$ \\
\hline A1 & 5.1236 & 5.0972 & 10.2208 & 0.0263 \\
C1 & 1.6185 & 1.6263 & 3.2448 & -0.0078 \\
C2 & 1.6524 & 1.6445 & 3.2969 & 0.0078 \\
A2 & 4.9943 & 5.1990 & 10.1933 & -0.2047 \\
C3 & 2.5562 & 2.4575 & 5.0137 & 0.0987 \\
C4 & 2.5135 & 2.4941 & 5.0076 & 0.0194 \\
C5 & 2.3512 & 2.4693 & 4.8206 & -0.1181 \\
A3 & 5.3368 & 5.0852 & 10.4220 & 0.2516 \\
C6 & 1.6889 & 1.6605 & 3.3494 & 0.0284 \\
C7 & 1.7067 & 1.7351 & 3.4418 & -0.0284 \\
A4 & 5.4058 & 5.3716 & 10.7774 & 0.0342 \\
C8 & 2.7664 & 2.7146 & 5.4810 & 0.0519 \\
C9 & 2.7531 & 2.8465 & 5.5996 & -0.0933 \\
C10 & 2.7239 & 2.6825 & 5.4064 & 0.0415 \\
A5 & 5.3239 & 5.1619 & 10.4858 & 0.1620 \\
C11 & 2.6747 & 2.6296 & 5.3042 & 0.0451 \\
C12 & 2.5077 & 2.6296 & 5.1372 & -0.1219 \\
C13 & 2.6402 & 2.5858 & 5.2259 & 0.0544 \\
A6 & 4.8271 & 5.0966 & 9.9238 & -0.2695 \\
C14 & 2.6072 & 4.1326 & -1.0818 \\
C15 & 1.5614 & 3.1225 & -0.0003 \\
\hline & 1.5611 & & \\
\hline
\end{tabular}
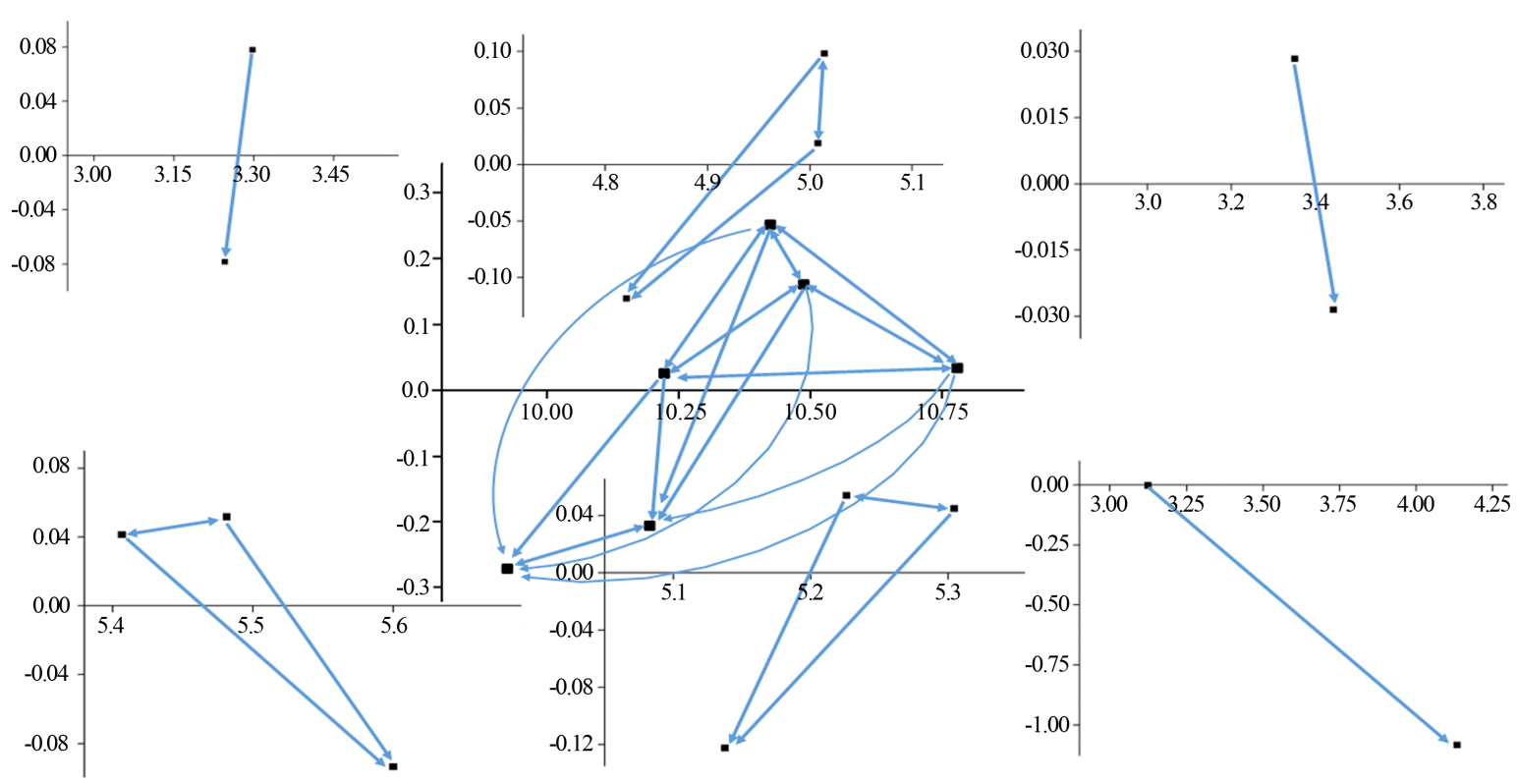

Figure 2. Network relationship map of expert. 


\subsection{Tourists}

In order to compare the differences among experts and tourists, questionnaires were also distributed through the tourism companies by tour guides and interviewed tourism experts. 300 questionnaires were distributed to international tourist who travels to Vietnam from February to July 2013, from 224 return only 185 respondents qualified for this research since in our study we chose the tourists who also used SNSs (FB, MySpace, Twitter) as our respondents. DEMATEL survey is difficult to understand and time consuming to complete, it is why 17 percent of respondents was eliminate from total respondents. Finally, the result of the DEMATEL survey was calculated using 185 respondents. Table 5 presents the total influence matrix of tourist DDMP and the threshold of tourist $\alpha=0.651$ is shown in Table 6 .

The results of level of influence between criteria, based on $d+r$ and $d-r$, of tourist are present in Table 7, which is also shown in Figure 3 as the network relations map.

\section{Discussion and Conclusion}

\subsection{Discussion}

By combining the DEMATEL and ANP methods, we found external search was the most important factor in the DDMP of tourists. External search plays an important role and has a direct influence on destination image and brand. According to the expert DEMATEL results, knowledge was the highest value variable for tourists before making a decision. In fact, they sometimes consider their knowledge to be the best choice. According to the degree of influential impact, $d+r$ provides an index of strength of influences given and received, and so the more positive the $d+r$ is, the greater is the degree of influence on other factors. On other hand, if $d-r$ is positive, the factor affects other factors; if $d-r$ is negative, then that factor is being influenced by other factors.

Accordingly, the NRM of DDMP can reduce risk and enhance the motivation of tourists to choose a destination by improving the information about a destination. Since the results of DEMATEL showed that the external search is a powerful factor that can have the greatest effect on other factors, the destination decision maker should provide more information about destination image to build up destination brand, which creates more opportunities for tourists to come.

Moreover, according to the results of this study, we can determine that information searching is most important step of DDMP. Therefore, we should improve it first by using the Internet, which is cheap and the fastest

Table 5. Tourist total influence matrix T.

\begin{tabular}{|c|c|c|c|c|c|c|c|c|c|c|c|c|c|c|c|}
\hline $\mathbf{T}$ & C1 & C2 & C3 & C4 & C5 & C6 & C7 & C8 & C9 & C10 & C11 & C12 & C13 & C14 & C15 \\
\hline C1 & 0.5402 & & 0.651 & & 0.6623 & 0.6521 & & & & & & 0.6631 & 0.6591 & .6668 & .6715 \\
\hline $\mathrm{C} 2$ & 0.5909 & 0.5718 & 0.6527 & 0.6675 & 0.6585 & 0.6516 & 0.6566 & 0.6798 & 0.7226 & 0.6505 & 0.6568 & 0.6638 & 0.657 & 0.6627 & 0.6664 \\
\hline C3 & 0.589 & 0.6277 & 0.5875 & 0.6616 & 0.6555 & 0.6535 & 0.6566 & 0.674 & 0.7168 & 0.6514 & 0.6565 & 0.6581 & 0.6532 & 0.661 & 0.6679 \\
\hline C4 & 0.5875 & 0.6223 & 0.6422 & 0.593 & 0.6578 & 0.6477 & 0.6494 & 0.6717 & 0.715 & 0.6486 & 0.6514 & 0.6536 & 0.6485 & 0.655 & 0.6566 \\
\hline C5 & 0.5884 & 0.6226 & 0.644 & 0.6552 & 0.5903 & 0.6458 & 0.6497 & 0.6735 & 0.7109 & 0.6507 & 0.6494 & 0.6549 & 0.652 & 0.6558 & 0.6614 \\
\hline C6 & 0.5916 & 0.6297 & 0.6482 & 0.6585 & 0.6563 & 0.5898 & 0.6607 & 0.6796 & 0.7187 & 0.6537 & 0.658 & 0.6634 & 0.6548 & 0.6656 & 0.6719 \\
\hline C7 & 0.5874 & 0.6261 & 0.6443 & 0.6533 & 0.6495 & 0.6445 & 0.5914 & 0.6766 & 0.7174 & 0.646 & 0.6515 & 0.6605 & 0.6544 & 0.6638 & 0.6638 \\
\hline C8 & 0.5897 & 0.6223 & 0.645 & 0.6558 & 0.6464 & 0.6419 & 0.6526 & 0.6107 & 0.7116 & 0.6506 & 0.6563 & 0.6575 & 0.6533 & 0.6597 & 0.665 \\
\hline C9 & 0.617 & 0.6551 & 0.673 & 0.6837 & 0.6827 & 0.6726 & 0.6793 & 0.7052 & 0.6775 & 0.6788 & 0.6861 & 0.6901 & 0.6825 & 0.6895 & 0.6959 \\
\hline C10 & 0.5986 & 0.6319 & 0.6553 & 0.6682 & 0.6622 & 0.6523 & 0.6622 & 0.6871 & 0.7288 & 0.5982 & 0.6653 & 0.6677 & 0.6615 & 0.673 & 0.674 \\
\hline C11 & 0.5955 & 0.6339 & 0.6538 & 0.661 & 0.6595 & 0.6501 & 0.6565 & 0.6765 & 0.7218 & 0.6558 & 0.5986 & 0.6694 & 0.6572 & 0.6684 & 0.6691 \\
\hline C12 & 0.5753 & 0.6128 & 0.6307 & 0.641 & 0.6357 & 0.6295 & 0.6378 & 0.6604 & 0.6972 & 0.6377 & 0.6413 & 0.5841 & 0.6402 & 0.6427 & 0.6494 \\
\hline C13 & 0.5916 & 0.6295 & 0.6494 & 0.6579 & 0.656 & 0.6496 & 0.6554 & 0.6769 & 0.7178 & 0.6554 & 0.6553 & 0.6648 & 0.5955 & 0.6654 & 0.6672 \\
\hline C14 & 0.5801 & 0.617 & 0.6349 & 0.6458 & 0.6434 & 0.636 & 0.6426 & 0.6656 & 0.7019 & 0.6391 & 0.641 & 0.6464 & 0.6428 & 0.5893 & 0.6519 \\
\hline C15 & 0.58 & 0.6118 & 0.6331 & 0.6409 & 0.6397 & 0.6358 & 0.6395 & 0.6608 & 0.703 & 0.6335 & 0.6409 & 0.6465 & 0.6451 & 0.6488 & 0.5909 \\
\hline
\end{tabular}


Table 6. Tourist total influence matrix T with threshold $\alpha=0.651$.

\begin{tabular}{|c|c|c|c|c|c|c|c|c|c|c|c|c|c|c|c|c|}
\hline$T$ & C1 & C2 & C3 & C4 & C5 & C6 & C7 & C8 & C9 & C10 & C11 & C12 & C13 & C14 & C15 & $d$ \\
\hline $\mathrm{C} 1$ & 0 & 0 & 0.651 & 0.6611 & 0.6623 & 0.6521 & 0.6577 & 0.6807 & 0.7257 & 0.6537 & 0.6615 & 0.6631 & 0.6591 & 0.6668 & 0.6715 & 8.666 \\
\hline C2 & 0 & 0 & 0.6527 & 0.6675 & 0.6585 & 0.6516 & 0.6566 & 0.6798 & 0.7226 & 0 & 0.6568 & 0.6638 & 0.657 & 0.6627 & 0.6664 & 7.996 \\
\hline C3 & 0 & 0 & 0 & 0.6616 & 0.6555 & 0.6535 & 0.6566 & 0.674 & 0.7168 & 0.6514 & 0.6565 & 0.6581 & 0.6532 & 0.661 & 0.6679 & 7.966 \\
\hline C4 & 0 & 0 & 0 & 0 & 0.6578 & 0 & 0 & 0.6717 & 0.715 & 0 & 0.6514 & 0.6536 & 0 & 0.655 & 0.6566 & 4.661 \\
\hline C5 & 0 & 0 & 0 & 0.6552 & 0 & 0 & 0 & 0.6735 & 0.7109 & 0.651 & 0 & 0.6549 & 0.652 & 0.6558 & 0.6614 & 5.315 \\
\hline C6 & 0 & 0 & 0 & 0.6585 & 0.6563 & 0 & 0.6607 & 0.6796 & 0.7187 & 0.6537 & 0.658 & 0.6634 & 0.6548 & 0.6656 & 0.6719 & 7.341 \\
\hline C7 & 0 & 0 & 0 & 0.6533 & 0 & 0 & 0 & 0.6766 & 0.7174 & 0 & 0.6515 & 0.6605 & 0.6544 & 0.6638 & 0.6638 & 5.341 \\
\hline C8 & 0 & 0 & 0 & 0.6558 & 0 & 0 & 0.6526 & 0 & 0.7116 & 0 & 0.6563 & 0.6575 & 0.6533 & 0.6597 & 0.665 & 5.312 \\
\hline C9 & 0 & 0.6551 & 0.673 & 0.6837 & 0.6827 & 0.6726 & 0.6793 & 0.7052 & 0.6775 & 0.6788 & 0.6861 & 0.6901 & 0.6825 & 0.6895 & 0.6959 & 9.552 \\
\hline C10 & 0 & 0 & 0.6553 & 0.6682 & 0.6622 & 0.6523 & 0.6622 & 0.6871 & 0.7288 & 0 & 0.6653 & 0.6677 & 0.6615 & 0.673 & 0.674 & 8.057 \\
\hline C11 & 0 & 0 & 0.6538 & 0.661 & 0.6595 & 0.651 & 0.6565 & 0.6765 & 0.7218 & 0.6558 & 0 & 0.6694 & 0.6572 & 0.6684 & 0.6691 & 8 \\
\hline C12 & 0 & 0 & 0 & 0 & 0 & 0 & 0 & 0.6604 & 0.6972 & 0 & 0 & 0 & 0 & 0 & 0 & 1.358 \\
\hline $\mathrm{C} 13$ & 0 & 0 & 0 & 0.6579 & 0.656 & 0 & 0.6554 & 0.6769 & 0.7178 & 0.6554 & 0.6553 & 0.6648 & 0 & 0.6654 & 0.6672 & 6.672 \\
\hline C14 & 0 & 0 & 0 & 0 & 0 & 0 & 0 & 0.6656 & 0.7019 & 0 & 0 & 0 & 0 & 0 & 0.6519 & 2.019 \\
\hline C15 & 0 & 0 & 0 & 0 & 0 & 0 & 0 & 0.6608 & 0.703 & 0 & 0 & 0 & 0 & 0 & 0 & 1.364 \\
\hline$r$ & 0 & 0.6551 & 3.2858 & 7.2837 & 5.9508 & 3.9332 & 5.9377 & 9.4684 & 10.687 & 4.5998 & 6.5986 & 7.967 & 6.585 & 7.9867 & 8.6825 & \\
\hline
\end{tabular}
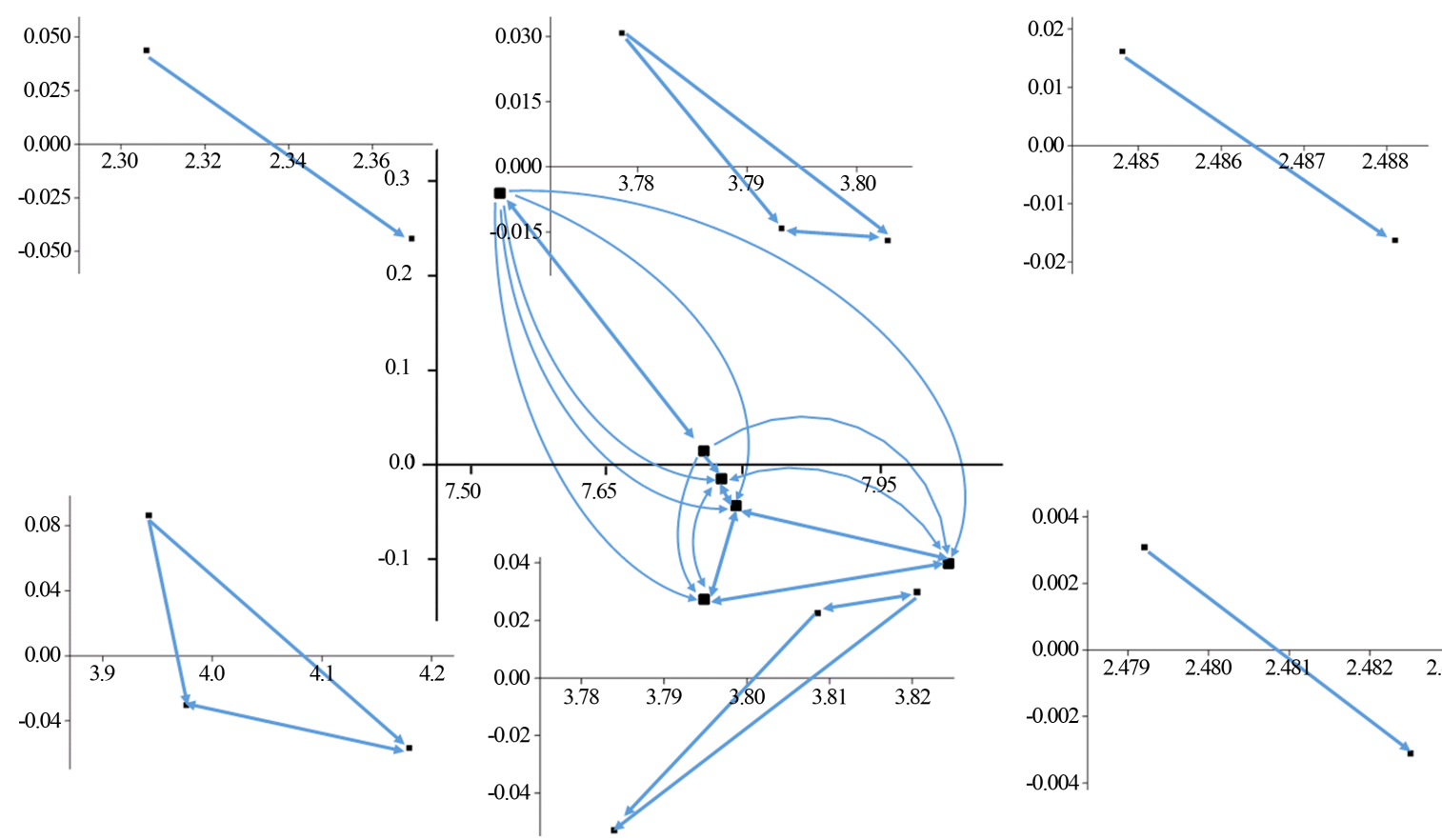

Figure 3. Network relationship map of tourists.

way to transfer information to tourists, and then to build up a strong destination image and brand for all destinations. Strategy makers should direct their attention to not only the decision-making process of the expert, but also to that of the tourist. Experts and tourist all recognize that searching information through the Internet must come first and will affect the remaining dimensions. Therefore, tourism organizations and strategy managers should concentrate resources on the Internet by using SNSs (two-way communication) to attract more tourists. 
Table 7. Tourist criteria influence-DEMATEL survey.

\begin{tabular}{lcccc}
\hline & $\boldsymbol{d}$ & $\boldsymbol{r}$ & $\boldsymbol{d}+\boldsymbol{r}$ & $\boldsymbol{d}-\boldsymbol{r}$ \\
\hline A1 & 3.9103 & 3.6221 & 7.5324 & 0.2882 \\
C1 & 1.1750 & 1.1311 & 2.3060 & 0.0439 \\
C2 & 1.1627 & 1.2066 & 2.3692 & -0.0439 \\
A2 & 3.8805 & 3.8951 & 7.7756 & -0.0146 \\
C3 & 1.9047 & 1.8738 & 3.7785 & 0.0309 \\
C4 & 1.8930 & 1.9098 & 3.8028 & -0.0169 \\
C5 & 1.8895 & 1.9036 & 3.7931 & -0.0141 \\
A3 & 3.8874 & 3.8717 & 7.7591 & 0.0157 \\
C6 & 1.2505 & 1.2343 & 2.4848 & 0.0162 \\
C7 & 1.2360 & 1.2521 & 2.4881 & -0.0162 \\
A4 & 3.9599 & 4.0638 & 8.0237 & -0.1038 \\
C8 & 1.9728 & 2.0030 & 3.9758 & -0.0301 \\
C9 & 2.0615 & 2.1179 & 4.1794 & -0.0564 \\
C10 & 2.0140 & 1.9275 & 3.9415 & 0.0865 \\
A5 & 3.8745 & 3.9171 & 7.7916 & -0.0427 \\
C11 & 1.9252 & 1.8952 & 3.8205 & 0.0300 \\
C12 & 1.8656 & 1.9183 & 3.7839 & -0.0527 \\
C13 & 1.9156 & 1.8929 & 3.8085 & 0.0227 \\
A6 & 3.8067 & 3.9495 & 7.7561 & -0.1428 \\
C14 & 1.2411 & 1.2380 & 2.4792 & 0.0031 \\
C15 & 1.2397 & 2.4825 & -0.0031 \\
\hline & & & & \\
\hline
\end{tabular}

\subsection{Conclusions}

This study aimed to determine the causal relationship among DDMP criteria by adopting a MCDM approach. In order to identify the key factors' impact on DDMP, this study has found that there is a causal relationship among the six dimension of DDMP, and that they are all interrelated and ultimately lead to tourist satisfaction. According to the results of both the tourist and expert survey, the external search dimension plays the most important role in the tourist's DDMP (Table 8). This supports the results found by Hyde [40], which state that tourists are most likely to research their trip in detail using external search information before the trip. Moreover, this research also supports the argument by [63] that social websites represent one of the most powerful search methods and play an important role within the context of trip planning. It can also be concluded that a tourist's destination choice is influenced by the information-search process.

Furthermore, by determining the weight of all criteria through the combined ANP and DEMATEL method, the results show the difference between the expert survey and tourist survey, especially when considering which factor is the most important factor. For example, the experts consider destination characteristic as the second most important factor, whereas the tourists think choice set is the second, although choice set is the fifth on the expert list.

According to the priority/weight list, the research showed the bias between the tourists and experts when they considered the rate of influence factors.

\subsection{Implications}

Based on the result of ANP and the impact relationship map acquired from DEMATEL, a strategy map was obtained based on the network relationship map to provide suggestions for the tourism industry to develop their 
Table 8. Tourists vs. experts DANP rankings.

\begin{tabular}{|c|c|c|c|c|c|c|c|}
\hline DANP Results & Experts Ranking & Tourists Ranking & $\begin{array}{l}\text { Global } \\
\text { Weight }\end{array}$ & $\begin{array}{l}\text { Experts Global } \\
\text { Ranking }\end{array}$ & $\begin{array}{l}\text { Tourists Global } \\
\text { Ranking }\end{array}$ & $\begin{array}{l}\text { Experts Local } \\
\text { Ranking }\end{array}$ & $\begin{array}{c}\text { Tourists Local } \\
\text { Ranking }\end{array}$ \\
\hline \multirow[t]{2}{*}{ A1 } & 4 & 6 & $\mathrm{C} 1$ & 4 & 6 & 2 & 2 \\
\hline & & & $\mathrm{C} 2$ & 3 & 5 & 1 & 1 \\
\hline \multirow[t]{3}{*}{ A2 } & 2 & 4 & $\mathrm{C} 3$ & 13 & 15 & 3 & 3 \\
\hline & & & $\mathrm{C} 4$ & 10 & 10 & 1 & 1 \\
\hline & & & $\mathrm{C} 5$ & 12 & 13 & 2 & 2 \\
\hline \multirow[t]{2}{*}{ A3 } & 6 & 5 & C6 & 6 & 4 & 2 & 2 \\
\hline & & & C7 & 1 & 3 & 1 & 1 \\
\hline \multirow[t]{3}{*}{ A4 } & 1 & 1 & C8 & 8 & 8 & 2 & 2 \\
\hline & & & C9 & 7 & 7 & 1 & 1 \\
\hline & & & C10 & 9 & 14 & 3 & 3 \\
\hline \multirow[t]{3}{*}{ A5 } & 3 & 3 & C11 & 11 & 11 & 1 & 2 \\
\hline & & & C12 & 15 & 9 & 3 & 1 \\
\hline & & & C13 & 14 & 12 & 2 & 3 \\
\hline \multirow[t]{2}{*}{ A6 } & 5 & 2 & C14 & 2 & 2 & 1 & 2 \\
\hline & & & C15 & 5 & 1 & 2 & 1 \\
\hline
\end{tabular}

strategies and attract more tourists to their destinations. This research has highlighted the key criteria and their interrelationships, offering a more comprehensive DDMP model which can serve as a reference for national tourism organizations that build up and promote their country's destination brand. Moreover, the interrelationship of important criteria identified in this study will also provide assistance for further researchers to study the key factors impacting DDMP from both expert and tourist perspectives.

\section{References}

[1] Zhang, Z., Ye, Q., Law, R. and Li, Y. (2010) The Impact of E-Word-of-Mouth on the Online Popularity of Restaurants: A Comparison of Consumer Reviews and Editor Reviews. International Journal of Hospitality Management, 29, 694-700. http://dx.doi.org/10.1016/j.ijhm.2010.02.002

[2] Pearce, D.G. and Schott, C. (2005) Tourism Distribution Channels: The Visitors' Perspective. Journal of Travel Research, 44, 50-63. http://dx.doi.org/10.1177/0047287505276591

[3] Wolfe, K. and Hsu, C.H.C. (2004) An Application of the Social Psychological Model of Tourism Motivation. International Journal of Hospitality \& Tourism Administration, 5, 29-47. http://dx.doi.org/10.1300/J149v05n01_02

[4] Heidemann, J., Klier, M. and Probst, F. (2012) Online Social Networks: A Survey of a Global Phenomenon. Computer Networks, 56, 3866-3878. http://dx.doi.org/10.1016/j.comnet.2012.08.009

[5] Gretzel, U. and Yoo, K. (2008) Use and Impact of Online Travel Reviews. In: O’Connor, P., Höpken, W. and Gretzel, U., Eds., Information and Communication Technologies in Tourism 2008, Springer Vienna, Vienna, 35-46. http://dx.doi.org/10.1007/978-3-211-77280-5_4

[6] Jenkin, H.J. (2010) The Impact of Social Networking Mediums on the Decision Making Process of Tourists: A Case Study of Stray Ltd and Spaceships New Zealand Ltd. Master Degree, University of Waikato, Hamilton.

[7] Wong, J.-Y. and Yeh, C. (2009) Tourist Hesitation in Destination Decision Making. Annals of Tourism Research, 36, 6-23. http://dx.doi.org/10.1016/j.annals.2008.09.005

[8] Smallman, C. and Moore, K. (2010) Process Studies of Tourists’ Decision-Making. Annals of Tourism Research, 37, 397-422. http://dx.doi.org/10.1016/j.annals.2009.10.014

[9] Saaty, T.L. (2001) Decision Making with Dependence and Feedback: The Analytic Network Process: The Organization and Prioritization of Complexity. Rws Publications. 
[10] Mill, R.C. and Morrison, A.M. (2002) The Tourism System. Kendall Hunt Pub, Dubuque.

[11] Goeldner, C.R. and Ritchie, J.R.B. (2009) Tourism: Principles, Practices, Philosophies. Wiley.

[12] Li, M. and Cai, L.A. (2012) The Effects of Personal Values on Travel Motivation and Behavioral Intention. Journal of Travel Research, 51, 473-487. http://dx.doi.org/10.1177/0047287511418366

[13] Drewartin, M., Woodside, A., Huang, S. and Hsu, C.H.C. (2009) Travel Motivation: Linking Theory to Practice. International Journal of Culture, Tourism and Hospitality Research, 3, 287-295. http://dx.doi.org/10.1108/17506180910994505

[14] Maslow, A.H. (1943) A Theory of Human Motivation. Psychological Review, 50, 370-396. http://dx.doi.org/10.1037/h0054346

[15] Dann, G.M.S. (1977) Anomie, Ego-Enhancement and Tourism. Annals of Tourism Research, 4, 184-194. http://dx.doi.org/10.1016/0160-7383(77)90037-8

[16] Richards, G. (2002) Tourism Attraction Systems: Exploring Cultural Behavior. Annals of Tourism Research, 29, 10481064. http://dx.doi.org/10.1016/S0160-7383(02)00026-9

[17] Xiang, Z., Wöber, K. and Fesenmaier, D.R. (2008) Representation of the Online Tourism Domain in Search Engines. Journal of Travel Research, 47, 137-150. http://dx.doi.org/10.1177/0047287508321193

[18] Assael, H. (1984) Consumer Behavior and Marketing Action. Kent Pub. Co.

[19] Fodness, D. and Murray, B. (1997) Tourist Information Search. Annals of Tourism Research, 24, 503-523. http://dx.doi.org/10.1016/S0160-7383(97)00009-1

[20] Kerstetter, D. and Cho, M.-H. (2004) Prior Knowledge, Credibility and Information Search. Annals of Tourism Research, 31, 961-985. http://dx.doi.org/10.1016/j.annals.2004.04.002

[21] Kim, Y.A. and Srivastava, J. (2007) Impact of Social Influence in E-Commerce Decision Making. Proceedings of the 9th International Conference on Electronic Commerce, Minneapolis, 19-22 August 2007, 293-302. http://dx.doi.org/10.1145/1282100.1282157

[22] Bamberg, S., Ajzen, I. and Schmidt, P. (2003) Choice of Travel Mode in the Theory of Planned Behavior: The Roles of Past Behavior, Habit, and Reasoned Action. Basic and Applied Social Psychology, 25, 175-188. http://dx.doi.org/10.1207/S15324834BASP2503 01

[23] Madden, T.J., Ellen, P.S. and Ajzen, I. (1992) A Comparison of the Theory of Planned Behavior and the Theory of Reasoned Action. Personality and Social Psychology Bulletin, 18, 3-9. http://dx.doi.org/10.1177/0146167292181001

[24] Woodside, A.G. and Jacobs, L.W. (1985) Step Two in Benefit Segmentation: Learning the Benefits Realized by Major Travel Markets. Journal of Travel Research, 24, 7-13. http://dx.doi.org/10.1177/004728758502400102

[25] Moutinho, L. (1987) Consumer Behaviour in Tourism. European Journal of Marketing, 21, 5-44. http://dx.doi.org/10.1108/EUM0000000004718

[26] Sirakaya, E. and Woodside, A.G. (2005) Building and Testing Theories of Decision Making by Travellers. Tourism Management, 26, 815-832. http://dx.doi.org/10.1016/j.tourman.2004.05.004

[27] Fuller, D., Wilde, S., Hanlan, J. and Mason, S. (2007) Destination Decision Making in Tourism Regions on Australia’s East Coast, Vol. 07-07.

[28] Middleton, V.T.C. (1994) Marketing in Travel and Tourism. Butterworth-Heinemann, Oxford.

[29] Devesa, M., Laguna, M. and Palacios, A. (2010) The Role of Motivation in Visitor Satisfaction: Empirical Evidence in Rural Tourism. Tourism Management, 31, 547-552. http://dx.doi.org/10.1016/j.tourman.2009.06.006

[30] Um, S. and Crompton, J.L. (1990) Attitude Determinants in Tourism Destination Choice. Annals of Tourism Research, 17, 432-448. http://dx.doi.org/10.1016/0160-7383(90)90008-F

[31] Plog, S. (2001) Why Destination Areas Rise and Fall in Popularity: An Update of a Cornell Quarterly Classic. The Cornell Hotel and Restaurant Administration Quarterly, 42, 13-24. http://dx.doi.org/10.1016/S0010-8804(01)81020-X

[32] Fridgen, J. (1991) Dimensions of Tourism. Educational Institute, American Hotel \& Motel Association, Indiana.

[33] Beerli, A. and Martín, J.D. (2004) Factors Influencing Destination Image. Annals of Tourism Research, 31, 657-681. http://dx.doi.org/10.1016/j.annals.2004.01.010

[34] Chon, K.-S. (1991) Tourism Destination Image Modification Process: Marketing Implications. Tourism Management, 12, 68-72. http://dx.doi.org/10.1016/0261-5177(91)90030-W

[35] Gnoth, J. (1997) Tourism Motivation and Expectation Formation. Annals of Tourism Research, 24, $283-304$. http://dx.doi.org/10.1016/S0160-7383(97)80002-3

[36] Cai, L.A. (2002) Cooperative Branding for Rural Destinations. Annals of Tourism Research, 29, 720-742. http://dx.doi.org/10.1016/S0160-7383(01)00080-9 
[37] Ho, C.-I., Lin, M.-H. and Chen, H.-M. (2012) Web Users' Behavioural Patterns of Tourism Information Search: From Online to Offline. Tourism Management, 33, 1468-1482. http://dx.doi.org/10.1016/j.tourman.2012.01.016

[38] Sharon, E.B. and Smith, S.M. (1987) External Search Effort: An Investigation across Several Product Categories. Journal of Consumer Research, 14, 83-95. http://dx.doi.org/10.1086/209095

[39] DiPietro, R.B., Wang, Y., Rompf, P. and Severt, D. (2007) At-Destination Visitor Information Search and Venue Decision Strategies. International Journal of Tourism Research, 9, 175-188. http://dx.doi.org/10.1002/jtr.600

[40] Hyde, K.F. (2008) Information Processing and Touring Planning Theory. Annals of Tourism Research, 35, $712-731$. http://dx.doi.org/10.1016/j.annals.2008.05.001

[41] Shankar, V., Smith, A.K. and Rangaswamy, A. (2003) Customer Satisfaction and Loyalty in Online and Offline Environments. International Journal of Research in Marketing, 20, 153-175. http://dx.doi.org/10.1016/S0167-8116(03)00016-8

[42] Akehurst, G. (2009) User Generated Content: The Use of Blogs for Tourism Organisations and Tourism Consumers. Service Business, 3, 51-61. http://dx.doi.org/10.1007/s11628-008-0054-2

[43] Gretzel, U., Hwang, Y. and Fesenmaier, D. (2012) Informing Destination Recommender Systems Design and Evaluation through Quantitative Research. International Journal of Culture, Tourism and Hospitality Research, 6, 297-315.

[44] Boyd, D.M. and Ellison, N.B. (2007) Social Network Sites: Definition, History, and Scholarship. Journal of ComputerMediated Communication, 13, 210-230. http://dx.doi.org/10.1111/j.1083-6101.2007.00393.x

[45] Pan, B., MacLaurin, T. and Crotts, J.C. (2007) Travel Blogs and the Implications for Destination Marketing. Journal of Travel Research, 46, 35-45. http://dx.doi.org/10.1177/0047287507302378

[46] Gursoy, D. and McCleary, K.W. (2004) An Integrative Model of Tourists' Information Search Behavior. Annals of Tourism Research, 31, 353-373. http://dx.doi.org/10.1016/j.annals.2003.12.004

[47] Miguens, J., Baggio, E. and Costa, C. (2008) Social Media and Tourism Destinations: Tripadvisor Case Study. Advances in Tourism Research, Aveiro, 26-28 May 2008, 1-6.

[48] Kattiyapornpong, U. and Miller, K.E. (2007) Differences within and between Travel Preference, Planned Travel and Choice Behavior of Australians Traveling to Asian and Overseas Destinations. CAUTHE 2007: Tourism-Past Achievements, Future Challenges, Sydney.

[49] Dwyer, L., Forsyth, P. and Rao, P. (2000) The Price Competitiveness of Travel and Tourism: A Comparison of 19 Destinations. Tourism Management, 21, 9-22. http://dx.doi.org/10.1016/S0261-5177(99)00081-3

[50] Pizam, A. and Mansfeld, Y. (1999) Consumer Behavior in Travel and Tourism. Haworth Hospitality Press.

[51] Becken, S. and Schiff, A. (2011) Distance Models for New Zealand International Tourists and the Role of Transport Prices. Journal of Travel Research, 50, 303-320. http://dx.doi.org/10.1177/0047287510362919

[52] Decrop, A. and Snelders, D. (2005) A Grounded Typology of Vacation Decision-Making. Tourism Management, 26, 121-132. http://dx.doi.org/10.1016/j.tourman.2003.11.011

[53] Money, R.B. and Crotts, J.C. (2003) The Effect of Uncertainty Avoidance on Information Search, Planning, and Purchases of International Travel Vacations. Tourism Management, 24, 191-202. http://dx.doi.org/10.1016/S0261-5177(02)00057-2

[54] Decrop, A. (2010) Destination Choice Sets: An Inductive Longitudinal Approach. Annals of Tourism Research, 37, 93115. http://dx.doi.org/10.1016/j.annals.2009.08.002

[55] Arsal, I., Woosnam, K.M., Baldwin, E.D. and Backman, S.J. (2010) Residents as Travel Destination Information Providers: An Online Community Perspective. Journal of Travel Research, 49, 400-413. http://dx.doi.org/10.1177/0047287509346856

[56] Fontela, E. and Gabus, A. (1972) World Problems an Invitation to Further Thought within the Framework of DEMATEL. Battelle Geneva Research Centre, Geneva.

[57] Fontela, E. and Gabus, A. (1976) The DEMATEL Observer. Battelle Geneva Research Center, Geneva.

[58] Wu, W.-W. and Lee, Y.-T. (2007) Developing Global Managers’ Competencies Using the Fuzzy DEMATEL Method. Expert Systems with Applications, 32, 499-507. http://dx.doi.org/10.1016/j.eswa.2005.12.005

[59] Shen, J.-L. and Liu, Y.-M. (2011) Integrated Multi-Criteria Decision-Making (MCDM) Method Combined with Decision Making Trial and Evaluation Laboratory (DEMATEL) and Analytic Network Process (ANP) in Food Supplier Selection. African Journal of Business Management, 6, 4595-4602.

[60] Liu, C.-H., Tzeng, G.-H. and Lee, M.-H. (2012) Improving Tourism Policy Implementation-The Use of Hybrid MCDM Models. Tourism Management, 33, 413-426. http://dx.doi.org/10.1016/j.tourman.2011.05.002

[61] Chen, F.-H., Hsu, T.-S. and Tzeng, G.-H. (2011) A Balanced Scorecard Approach to Establish a Performance Evaluation and Relationship Model for Hot Spring Hotels Based on a Hybrid MCDM Model Combining DEMATEL and 
ANP. International Journal of Hospitality Management, 30, 908-932. http://dx.doi.org/10.1016/j.ijhm.2011.02.001

[62] Sumrit, D. and Anuntavoranich, P. (2012) Using DEMATEL Method to Analyze the Causal Relations on Technological Innovation Capability Evaluation Factors in Thai Technology-Based Firms. International Transaction Journal of Engineering, Management, \& Applied Sciences \& Technologies, 4, 81-103.

[63] Xiang, Z. and Gretzel, U. (2010) Role of Social Media in Online Travel Information Search. Tourism Management, 31, 179-188. http://dx.doi.org/10.1016/j.tourman.2009.02.016 


\section{Appendix}

The DEMATEL method in this study following below steps:

Step 1: Calculate the original average matrix

We assume $Z$ experts in this study, who were asked to indicate the impact that they estimated through a scale ranging of the matrix and to evaluate the relationships among elements. A scale, ranging from 0 to 4 , representing no influence to very high influence, was used (Table 3). Each respondent was asked to indicate the degree to which he or she believed a factor $i$ affects factor $j$ notated as $x_{i j}$. When $i=j$, the value of $x_{i j}$ is set to 0 . The score by each expert gave us an $n \times n$ non-negative answer matrix $X^{k}=\left[x_{i j}^{k}\right]$, with $1 \leq k \leq Z$. Therefore, $x$, $x^{2}, x^{3}, \cdots, x^{n}$ are the answer matrices for each of the $Z$ experts, and each element of $x^{k}$ is a integer denoted by $\left[x_{i j}^{k}\right]$. The arithmetic average method is used to incorporate all expert opinions, and then the initial average matrix $\boldsymbol{X}$ as presented below assumes an $n$ variable impact within the decision-making model.

$$
X=\left[\begin{array}{ccccc}
0 & \cdots & x_{1 j} & \cdots & x_{1 n} \\
\vdots & \ddots & \vdots & \ddots & \vdots \\
x_{n 1} & \cdots & x_{1 i} & \cdots & 0
\end{array}\right]
$$

Step 2: Establishing the structure model and calculating the direct-influence matrix.

The next matrix, $\mathbf{N}$, is obtained by normalizing the average matrix $\boldsymbol{X}$. The matrix is normalized by calculating the sum of rows and columns separately. The maximum values are obtained by using the equation (2), then dividing $\boldsymbol{X}$ by $\boldsymbol{N}$, providing the normalized initial direct-relation matrix A (3). Each value in matrix $\boldsymbol{A}$ is between 0 and 1:

$$
\begin{gathered}
N=\max \left\{\max \sum_{j=0}^{n}\left(x_{i j}\right), \max \sum_{i=0}^{n} x_{i j}\right\} i, j=(1,2, \cdots, n) \\
A=X / N
\end{gathered}
$$

Step 3: Calculate the full relation matrix.

The normalized direct-influence matrix $\boldsymbol{A}$ by the summation of $i$ or $j$ is obtained. The full relation matrix $\boldsymbol{T}$ is calculated by equation (4) and equation (5) with the " $I$ " denoted as the $n \times n$ identity matrix:

$$
\begin{gathered}
\quad T=\sum_{1}^{\infty} A^{n} \\
T=A+A^{2}+A^{3}+\cdots+A^{\infty} \\
=A\left(I+A+A^{2}+\cdots+A^{q-1}\right)\left[(I-A)(I-A)^{-1}\right] \\
=A\left(I-A^{q}\right)(I-A)^{-1}
\end{gathered}
$$

The requirements are: $T=A(I-A)^{-1}$, when $q \rightarrow \infty, A^{q}=[0]_{n \times n}$, where $N=\left[x_{i j}\right]_{n \times n}$, $0 \leq x_{i j}<1,0<\left(\sum_{j=1}^{n} x_{i j}, \sum_{i=1}^{n} x_{i j}\right) \leq 1$

Step 4: Calculating value and analyzing the result.

Let $t_{i j}(i, j=1,2, \cdots, n)$ be the elements of the total-relation matrix $T$, then the sum of rows and the sum of columns, denoted as vector $d_{i}$ and $r_{j}$, using equation (6) and (7).

$$
\begin{gathered}
T=\left[t_{i j}\right]_{n \times n}, i j(\in: 1,2, \cdots, n), \\
d=\left[\sum_{j=1}^{n} t_{i j}\right]_{n \times 1} \\
r=\left[\sum_{i=1}^{n} t_{i j}\right]_{1 \times n},
\end{gathered}
$$

where $d_{i}$ represents the sum by taking element $i$ as the cause to influence other elements, $r_{j}$ represents the sum by taking element $j$ as the result being influence by other elements. The horizontal axis vector $(d+r)$ is made by adding vector $d$ to vector $r$, called prominence, and importantly indicates the element's degree of influence and 
being influence. Similarly, the vertical axis vector $(d-r)$ is made by deducting vector $\mathrm{d}$ from vector $\mathrm{r}$, called relation, and separates criteria into a cause group and an affect group. Conceptually, when the value $(d-r)$ is positive, the criterion belongs to the cause group. When the $(d-r)$ is negative, the criterion belongs to the effect group. Hence, causal diagrams can visualize the complicated causal relationships between criteria into a visible structural model, providing valuable insight for problem solving. Furthermore, with the help of a causal diagram, we may make proper decisions by recognizing the difference between cause and effect criteria.

Integrated method

In this study, tourist DDMP is presented to illustrate the application of the DEMATEL and ANP for proposing the most important criteria, which affect other criteria and the weight of each criterion. A hybrid MCDM model, combining the DEMATEL technique with the ANP method (DANP), has been widely applied in different decision-making problems with great success. It also can be used to solve dependence and feedback problems.

Step 5 Weights $=\lim _{k \rightarrow \infty} W_{w}^{k}$

Then, we raise the weighted super matrix to limiting power suntil we get the super matrix converged to get the global priority vectors or weights.

Finally, we limit the weighted super matrix by raising it to a sufficiently large power until the super matrix has converged and has become a long term stable super matrix to get the global priority vectors called ANP weights, such as $\lim k->1(W a) k$.

\section{Submit or recommend next manuscript to SCIRP and we will provide best service for you:}

Accepting pre-submission inquiries through Email, Facebook, LinkedIn, Twitter, etc.

A wide selection of journals (inclusive of 9 subjects, more than 200 journals)

Providing 24-hour high-quality service

User-friendly online submission system

Fair and swift peer-review system

Efficient typesetting and proofreading procedure

Display of the result of downloads and visits, as well as the number of cited articles

Maximum dissemination of your research work

Submit your manuscript at: http://papersubmission.scirp.org/ 